Special issue of the 3rd International Conference on Computational and Experimental Science and Engineering (ICCESEN 2016)

\title{
Lightweight Geopolymer Made of Pumice with Various Aluminum Powder Ratios
}

\author{
S. ÇETinkAYA*, H. KurT And N. KÜtÜK \\ Cumhuriyet University, Department of Chemical Engineering, 58140, Sivas, Turkey
}

\begin{abstract}
In this work, a lightweight geopolymer was prepared using various mass proportions of extra fine aluminum powder and pumice stone that is durable to heat and sound-proof. The effect of $\mathrm{NaOH}$ concentration, aluminum mass ratio, the curing temperature and the curing time of the mixture on the compressive strength of the lightweight geopolymers were examined. The concentration of $\mathrm{NaOH}$ was found to be $2 \mathrm{M}$ while the mass proportion of $\mathrm{Na}_{2} \mathrm{SiO}_{3} / \mathrm{NaOH}$ was found to be 17.5 on the lightweight geopolymers that have the highest compressive strength and the best workability in experiments. The lightweight geopolymer attained the best compressive strength with $1.6 \mathrm{MPa}$ on the 28 th day of curing process at $40^{\circ} \mathrm{C}$. The mass proportion of aluminum used in the lightweight geopolymer was $2.5 \%$ as the density of the lightweight geopolymer obtained was $0.9 \mathrm{~g} / \mathrm{cm}^{3}$. Their properties were examined using the Fourier transform infrared spectroscopy, X-ray diffraction, and scanning electron microscopy.
\end{abstract}

DOI: 10.12693/APhysPolA.132.544

PACS/topics: lightweight geopolymers, pumice, compressive strength, aluminum powder

\section{Introduction}

Geopolymer materials have attracted attention as a new class of construction materials with amorphous to semi-crystalline nature due to their notable fire and chemical resistance, low density, low cost, easy processing, environmentally friendly nature, and excellent mechanical properties [1, 2]. Nowadays, lightweight (LW) construction materials are used to reduce the weight of building structures and improve thermal insulation efficiency of buildings $[3,4]$. LW geopolymers made with natural aggregates and inorganic material exhibit great combination of thermal and mechanical properties [5]. The geopolymeric reaction occurs when alumina-silicate oxides reacts with alkali $(\mathrm{NaOH}, \mathrm{KOH})$ and soluble alkali polysilicates. Alumina silicate materials such as fly ash, blast furnace slag, and metakaolin are commonly used to prepare geopolymers and LW geopolymers but there is no report on preparation of LW geopolymer from pumice [6]. Pumice also used in concrete and tested against radiation shielding [7, 8]. Herein, we prepared LW geopolymer using pumice as alumina-silicate materials and Al powder as foaming agent [3].

\section{Experimental}

Sodium silicate $\left(\mathrm{Na}_{2} \mathrm{SiO}_{3}\right)$ and $\mathrm{NaOH}$ were used as alkaline activators. $\mathrm{NaOH}$ and $\mathrm{Na}_{2} \mathrm{SiO}_{3}$ were mixed in a beaker for $2 \mathrm{~min}$. For the preparation of LW geopolymer, pumice was dry mixed by commercially pure aluminum powder (Al powder) with various weight ratio. Alkali activator was then added to the mixture and entire content was mixed for $5 \mathrm{~min}$. Finally, the specimens

*corresponding author; e-mail: cetinkaya.sevil@gmail.com were rapidly poured into cubic molds with dimensions $40 \times 40 \times 40 \mathrm{~mm}^{3}$. In order to investigate the effect of the alkaline activator on the compressive strength of the geopolymer material, a series of $\mathrm{NaOH}$ solution with concentrations of $1,2,3,5,10$, and $15 \mathrm{M}$ and wt $\% \mathrm{Al}$ powder of $0.5,1,1.68,2$, and 2.5 were used. Varying curing temperatures were applied on the prepared LW geopolymers such as at $25,40,60$, and $80^{\circ} \mathrm{C}$.

\section{Results and discussion}

Figure 1 shows the effect of weight of $\mathrm{Al}$ powder and $\mathrm{NaOH}$ concentration on compressive strength of LW geopolymers. It is seen from the figures that the compressive strength of LW geopolymers decreased with increase of $\% \mathrm{Al}$ powder until 2\% and then increased (Fig. 1a) while it first increased with increase of $\mathrm{NaOH}$ concentration until $2 \mathrm{M}$ and then decreased (Fig. 1b). The mass proportion of $\mathrm{Al}$ powder used in the lightweight pumice geopolymer was 2.5 in the experiments. The highest compressive strength was obtained as $1.6 \mathrm{MPa}$ at the $28 \mathrm{th}$ day of curing process at $40^{\circ} \mathrm{C}$ (Fig. 2).

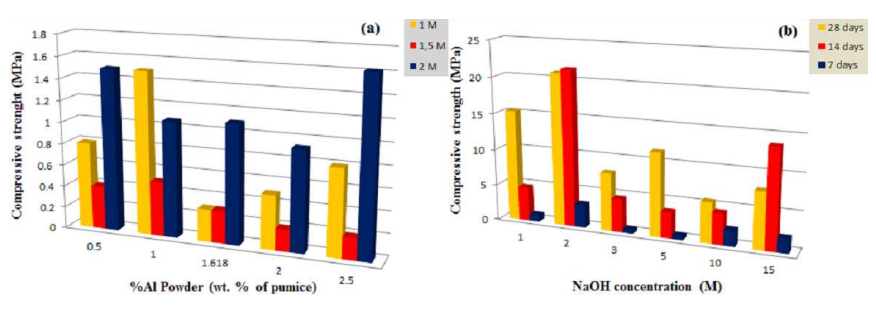

Fig. 1. (a) The effect of wt\% of $\mathrm{Al}$ powder in the mixture and (b) $\mathrm{NaOH}$ concentration on the compressive strength of lightweight geopolymer.

X-ray diffraction patterns and the Fourier transform infrared (FTIR) spectrum of $\mathrm{Al}$ powder, pumice and LW geopolymers by varying curing temperature are presented 


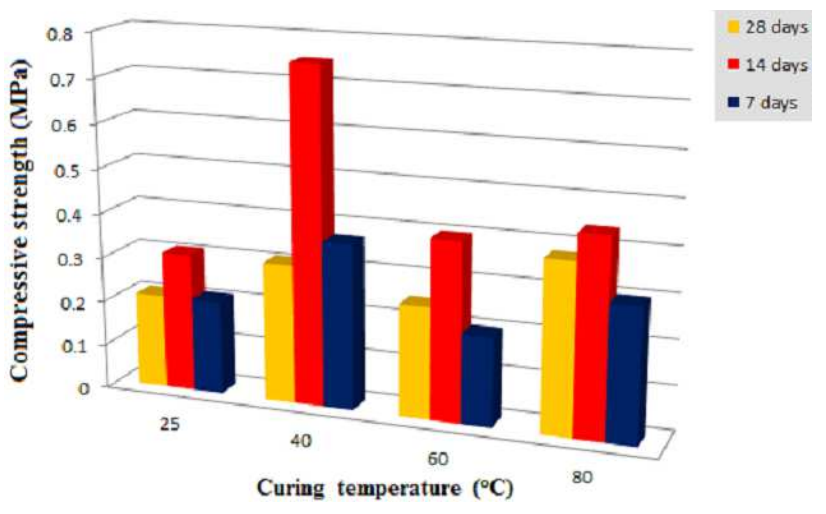

Fig. 2. Relations of compressive strength and curing temperature of lightweight geopolymer concrets.

in Fig. 3a and b, respectively. The characteristic diffraction peaks of pumice and $\mathrm{Al}$ powder were located at 23 , $28(2 \theta)$ and 40, 48, 65, and $80(2 \theta)$, respectively (Fig. 3a). $\mathrm{X}$-ray diffraction (XRD) pattern of LW geopolymer by varying curing temperature is similar to that of pure pumice such that there is no peak of Al powder. Figure $3 \mathrm{~b}$ illustrates FTIR spectra of LW geopolymer and its raw materials. The bands observed between 990 and $1000 \mathrm{~cm}^{-1}$ correspond to $\mathrm{Si}-\mathrm{O}$ and $\mathrm{Al}-\mathrm{O}$ stretching vibration bands of pumice. It is noted in the figure that there is no band that belongs to $\mathrm{Al}$ powder [6].

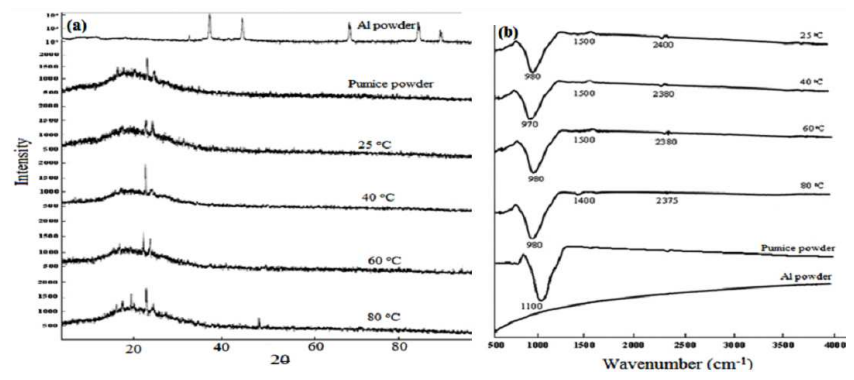

Fig. 3. (a) XRD patterns and (b) FTIR spectrum of $\mathrm{Al}$ powder, pumice and geopolymers by varying curing temperature (2 M NaOH; $\mathrm{Na}_{2} \mathrm{SiO}_{3} / \mathrm{NaOH} 17.5 ; \mathrm{Al}$ powder (wt of pumice) $2.5 \%$; curing time 28 days).

Scanning electron microscopy (SEM) micrographs of pumice, Al powder and LW geopolymers with varying curing temperatures are shown in Fig. 4. SEM observations of LW geopolymers indicate a hardened structure with increasing curing temperature. Also, it is seen that the LW geopolymers are more dense and homogeneous with increase of curing temperature.

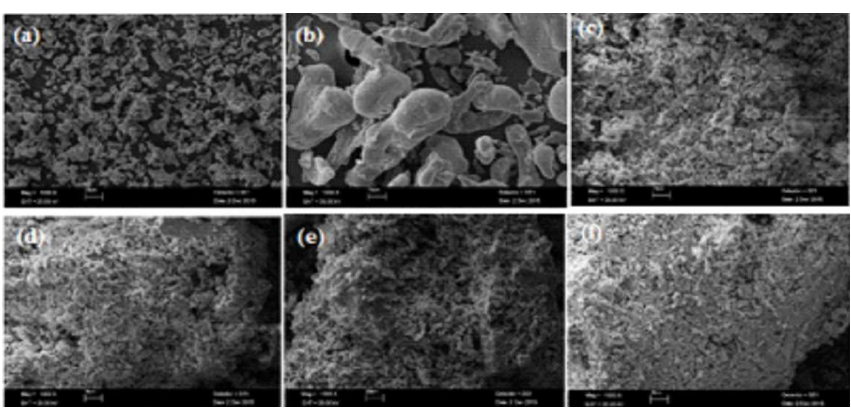

Fig. 4. SEM analyses of pumice, $\mathrm{Al}$ powder and geopolymers with varying curing temperatures: (a) pumice, (b) $\mathrm{Al}$ powder, (c) 25, (d) 40, (e) 60, (f) $80^{\circ} \mathrm{C}\left(2 \mathrm{M} \mathrm{NaOH} ; \mathrm{Na}_{2} \mathrm{SiO}_{3} / \mathrm{NaOH} 17.5 ; \mathrm{Al}\right.$ powder (wt of pumice) $2.5 \%$, curing time 28 days).

\section{Conclusion}

The LW geopolymers were successfully prepared through changing mass ratio of $\mathrm{Al}$ powder. The best compressive strength of $1.6 \mathrm{MPa}$ was reached at $2 \mathrm{M}$ concentration of $\mathrm{NaOH}, 17.5 \mathrm{Na}_{2} \mathrm{SiO}_{3} / \mathrm{NaOH}$ mass ratio, $2.5 \%$ weight of $\mathrm{Al}$ powder in the mixture on the 28 th day of curing process at $40^{\circ} \mathrm{C}$. The results show that the mass ratio of $\mathrm{Al}$ powder, $\mathrm{NaOH}$ concentration and curing temperature have great effect on compressive strength of LW geopolymers.

\section{Acknowledgments}

This work was supported by Cumhuriyet University Scientific Research Project (CUBAP), project numbered as M625.

\section{References}

[1] C. Villa, E.T. Pecina, R. Torres, L. Gomez, Construct. Build. Mater. 24, 2084 (2010).

[2] J. Temuujin, R.P. Williams, A. van Riessen, J. Mater. Process. Technol. 209, 5276 (2009).

[3] J.G. Sanjayan, A. Nazari, L. Chen, G.H. Nguyen, Construct. Build. Mater. 79, 236 (2015).

[4] T. Piotrowski, D.B. Tefelski, J.J. Sokolowska, B. Jaworska, Acta Phys. Pol. A 128, B-9 (2015).

[5] P. Posi, C. Teerachanwit, C. Tanutong, S. Limkamoltip, S. Lertnimoolchai, V. Sata, P. Chindaprasirt, Mater. Des. 52, 580 (2013).

[6] M.M. Yadollahi, A. Benli, R. Demirboğa, Construct. Build. Mater. 94, 767 (2015).

[7] I. Akkurt, H. Akyildirim, B. Mavı, Ş. Kilinçarslan, C. Başyı̆̆ıt, Acta Phys. Pol. A 121, 144 (2012).

[8] I. Akkurt, Nucl. Eng. Des. 252, 163 (2012). 